\title{
A GENEALOGY OF STATE CRIME IN INTERNATIONAL LAW: CONTRASTING CRIMINOLOGICAL PERSPECTIVES
}

\author{
Camilo Umaña
}

\begin{abstract}
In international public law, the concept of state crime has been extensively debated. For some international law commentators "[t]he concept of state responsibility for international crimes is juridically feasible and may be analyzed in terms of a criminal organization model or a corporate crime model” (Jørgensen 2000: 280); to others, "[t]he criminal state is juridically speaking a nonsense ... The punishability of the state is both a legal and a practical impossibility." (Drost 1959: 304). Although currently common legal understanding represents this notion as alien to the legal tradition, this term has a relevant place in the historical debates and development of international law. This paper discusses international law developments in contrast to criminological reflections relating to state crime, drawing attention to possible cross-references between these disciplines.
\end{abstract}

Keywords: state crime; international law; United Nations; Inter-American System of human rights

\section{Introduction}

In international public law, the concept of state crime has been extensively debated. For some international law commentators "[ $\mathrm{t}]$ he concept of state responsibility for international crimes is juridically feasible and may be analyzed in terms of a criminal organization model or a corporate crime model" (Jørgensen 2000: 280); to others, "[t]he criminal state is juridically speaking a nonsense . . . The punishability of the state is both a legal and a practical impossibility." (Drost 1959: 304). Although currently the common legal understanding represents this notion as alien to the legal tradition, this term has a relevant place on the historical debates and development of international law.

The first part of this paper presents main reflections about the concept of state crime from a criminological perspective focusing on theoretical approaches to crime. Although criminology is the leading field with regards to developments about state crime, "the issue of state crime has of course a genealogy, with a

University Externado of Colombia. 
provenance largely from the mid- to late-twentieth century. The domain in which this debate has mainly taken off is in the sphere of international law" (Vincent 2012: 67). Within the aforementioned genealogy, the work of the International Law Commission of the United Nations (hereinafter, ILC) on the codification of state responsibility is one of the first antecedents referring to this topic, constituting a landmark debate within international law. For this reason, the second part of this chapter will study the ILC discussions around state crime.

Exploring the obstacles, limitations and advantages the legal tradition confers on the notion of state crime certainly awakens different criminological and socio-legal reflections. Although there is no lineal connection between criminological and international law studies (cross-references are rare between these disciplines), when conducting an analysis of these subjects we realize that they raise similar issues.

\section{A Sociological Delimitation of State Crime}

It is difficult to trace the pioneer use of the term "state crime" in social sciences. ${ }^{1}$ Within criminology the term was introduced in the late 1960s (Barak 1990). According to Cohen (1993), "[t] he first significant confrontation with the subject came in the early phase of radical criminology in the late sixties. That favorite debate of the times - 'who are the real criminals?' - naturally turned attention from street crime to white collar/corporate crime and then to the wider notion of 'crimes of the powerful'. The particular context of the Vietnam War, pushed our slogans . . explicitly in the direction of "crimes of the state'." (Cohen 1993: 98).

One of the first explicit references to this term is to be found in Hannah Arendt's work. Arendt (1973) employed the term "state crime" when referring to criminal actions perpetrated for the extraordinary "survival" of the state (i.e. wars), or to conduct part of the regular modus operandi of certain political regimes (e.g. ordinary (wrong)doing of totalitarian governments). The first case, Arendt attributed to exceptional actions perpetrated for assuring the survival of the state; while, in the second case, she framed a political programme of action in accordance with which criminal conduct simply follows the typical course of action of certain regimes. In this last case, Arendt (1973) referred to totalitarian regimes which in her view implied the collapse of the traditional nation-state based on the rule of law into states ruled by racism, anti-Semitism and imperialism.

Arendt's work is a landmark for the concept because of its precedence but also because it developed a correlation between state crime and the political configuration of the governments, particularly exposing Totalitarism and Nazism as regimes organized around the practice of state criminal conduct. The extent of such correlation was however contested in criminological studies. Indeed, for some criminology commentators, state criminality "is not indigenous or symptomatic of any 
particular socio-economic formation ... [C]rimes by and of the state can be found globally. In other words, historically it has been the case that both democratic and undemocratic regimes have engaged in state criminality." (Barak 1990: 16). According to this, the political organization of the state is relevant for properly contextualizing state conduct, but it is not stricto sensu an element of the concept. After all, history has proved that different violations of rights have been perpetrated on behalf or in the name of states in the most diverse contexts and supported by the most diverse forms of governments (Rothe 2009), including democratic systems.

Within criminology, state crime was conceptually pioneered by William Chambliss (1989). His early studies on the subject focused on the issues of piracy, smuggling, plundering and other wrongdoing in which the state was a relevant actor. The use of this notion emerged in the discipline as a manifestation of the discussions around the role of the state with regard to the phenomenon of criminality as well as an expression of the concern for the crimes of the powerful and their restraint. Thus, this concept allowed criminology to challenge the double standard in accordance with which crimes against governments are real crimes while the misconduct by the state could not be understood as criminal (Ross 2003: 84). Furthermore, when criminology referred to state crime it aimed at urging for a reinstatement of its field of observation beyond the orthodox emphasis on street crime.

The category of state crime was part of the response coming from criminology against the lack of legal redress for the harm committed by powerful actors as well as by large economical corporations and states-compared to the widespread study and over-excited social perception of the crimes of the powerless. This subject of study was also part of a concern regarding the accountability of powerful actors and the characteristic social bias of the operation of the criminal justice.

Historically, the crimes of the powerful have managed to avoid or escape
criminalization and stigmatization. Time and again, these powerful criminal
activities have been conventionalized or neutralized by way of alliances,
negotiations, and justifications that undermine the moralizations of these
offenses (Carson 1979; Prins 2014; Ruggiero 2013). Concurrently, the legal
reactions to as well as the ideological rationalizations of elite offenses by capitalist
stateactors and otherdefenders ofthestatus quocontributetothis demoralization
of the crimes of the powerful and to the denial of victimhood and liability for
those harmed or injured. (Barak 2015:2)

The production of criminal legislation is indeed embedded in power relations. The question around who has the power to define criminal conduct is a matter of variable correlations of power related to the specificities of social relations. In other words, if we remove the criminal law reference, the problem of the effects of 
power does not disappear, but rather the relations of power that have to be observed become more widely dispersed. More importantly, if we remove a programme of reference for the observation, it becomes simply impossible to differentiate what is (not) a criminal event.

The text of Chambliss, Michalowski and Kramer (2010) is particularly useful for illustrating the problem of removing a clear reference to the observation of events as crimes. These authors assert that the study of state criminality should undertake inquiries on "crimes and social injuries of state power regardless of their status under law." (5). Following this view, Ross includes within the concept of state crime "those practices that, although they fall short of being officially declared illegal, are perceived by the majority of the population as illegal or socially harmful." (Ross 2000: 74; 2003: 87). In order to determine which conducts could be regarded as crimes, Green and Ward (2000) formulate a social audience test. In line with this test, state crimes are those offences that if they were noticed by a "significant social audience" (Ward 2013: 65) there would be a high likelihood of censure or sanction (Green and Ward 2000: 110).

Rothe qualified this definition as vague as far as it is unclear "what constitutes a social audience and which audiences may legitimately label behavior a crime." (2009: 6). In our view, there is a more basic problem: how would any audience (legitimate or not) be able to stabilize any observation of crimes without any previous programme of reference? Indeed, the audience deprived of an established and generalized reference would not be able to stabilize any normative expectations. In that case, an "audience" simply could not distinguish the phenomenon. Moreover, undertaking a social audience test would confine its results to the inscrutable decision of public opinion. Relying on the support of public opinion could discard harm when it becomes popular or if it is perceived as legitimate in a certain social setting.

The idea is that social audiences are able to detect crime related to a moral substratum, according to which, "criminal law is always and inevitably expressive, or perhaps it would be better to say constitutive, of a prevailing social morality adopted and enforced by the state." (MacCormick 2007: 211). Following this idea, a part of the literature distinguishes between mala in se (wrongdoing in nature) and mala prohibita (regulatory offences). In line with this distinction, mala in se are wrongdoing for which the observer does not need a reference to a criminal offence in order to be able to recognize a situation as criminal. On the contrary, the observer is able to identify other forms of wrongdoing as criminal only when the law prohibits them. How can we use this criterion and remain critical when the standard for observing crime is the erosion of a tradition, or an official way of life or to prevent the harmless violation of a taboo? ${ }^{2}$

Non-criminal law approaches to state crime have developed different references to observe the presence of state crime. Some have chosen a harms-based definition 
that emerges from the idea that crimes should be defined "in terms of needs-based social harms inflicted by the powerful on less powerful people, independent of formal legal institutions." (Friedrichs and Schwartz 2007: 4). In line with this trend, Matthews and Kauzlarich (2007) point out that the notion of state crime covers all state-prompted harms, even if they are not technically law-breaking. While this view avoids legal arguments, it establishes harm as its programme of reference.

The harm principle remains elusive and ambiguous. Indeed, the categories of injury, wrongdoing or harm are vague standards for determining the occurrence of a crime. There can be cases where harm is explicit but where the presence of a criminal situation is not, e.g. when someone cheats on a bet by taking advantage of that situation or when someone bullies another person. There can also be cases where the existence or not of harm is doubtful and contested but there can be a criminal action, e.g. cases of abortion that are criminal in certain jurisdictions in spite of a case-by-case determination on the existence of harm. Moreover, there can be non-grievance evils or harmless actions that can be considered as criminal and, as such, be enforced by the criminal law, e.g. the Canadian criminal code regards as a criminal offence polygamy or immoral theatrical performance.

Within non-criminal law approaches to state crime different commentators have developed a rights-based definition with the reference of universally defined human rights. (Doig 2011: 47). According to Schwendinger and Schwendinger (2014), (re)defining crime implies that criminologists redefine themselves not as the defenders of order (as when they adopt a concept of crime according to the law) but rather as the guardians of human rights. A rights-based definition asserts that state crime is an "organizational deviance involving the violation of human rights." (Green and Ward 2004: 2; also in Ward 2013). In line with this definition, human rights are not only legal norms, the breach of which constitutes a violation, rather, they are principles that can be violated independently of particular legal rules (Ward 2013).

This reference to the violation of human rights results in an open-ended definition of crime since every claim that an observer presents as a human rights violation becomes criminal - when human rights and criminal legislation are two faces of the same coin, either you fall in one or in the other. This poses serious conceptual and practical problems when determining the scope of the concept because the observer is not able to draw a clear indication for what is considered as (state) crime since all violations of human rights become a crime.

Not every human rights violation amounts to a crime. A multiplicity of human rights may be breached by acts that are not criminal. At the same time, there are a number of crimes that do not violate human rights; however, when a child does not have access to primary education or when workdays exceed the maximum legal ordinary working hours, there is a human rights violation but not necessarily a crime. We will come back to this later on. 
Considering the different problems when referring to the notion of crime, we agree with Stanley Cohen's call to use a "more restricted and literal use of the concept "state crime"" as both "more defensible and useful" (Cohen 1993: 98). What concept could be useful for drawing up clearer boundaries for the concept of (state) crime? The criminal-law approach addresses this question affirming that the definition of state crime should be constructed around legal definitions of criminal conduct in order to avoid the indistinctiveness of the concept. In line with this, the literature working with a legal framework is focused on the legal definitions as the point of reference to indicate the presence of crime (Matthews and Kauzlarich 2007: 47).

The pioneering criminology conceptualization developed by William Chambliss defines state crime as those "acts defined by law as criminal and committed by state officials in pursuit of their jobs as representatives of the state." (1989: 184). According to Kramer, Michalowski and Rothe this definition was problematic because it limited its scope to a "conventional definition of law" (2005: 54), exclusively regarding legal prohibitions on a nation-state basis. In a sense, this critique can open the floor for the argument that the notion of state crime is a logical self-contradiction "since the sovereign state is the only valid legal presupposition to the concept of crime. In this sense the concept of crime simply cannot logically transcend or indeed temporally precede the state." (Vincent 2012: 68).

In 1995, Chambliss integrated into his concept of state crime those behaviours violating "international agreements and principles established in the courts and treaties of international bodies" (9). The position of integrating domestic and international law as parameters of the distinction of a crime entailed the observation of a legal development: international law became a relevant source of criminal law. In order to identify which acts qualify as international crimes, Heller (2016) establishes that "the vast majority" of international criminal law scholars differentiate between "core" international crimes and other international criminal conducts - or conduct universally criminal under international law and conduct defined as criminal within domestic frameworks.

Chambliss's adoption of an international law parameter for delimiting criminal conduct was, to some degree, a response to the position against the use of a conventional definition of crime restricted to domestic legal prohibitions for state crime. This is because an international law definition could be understood as a form of independence from merely domestic parameters - often ambiguous and unsatisfactory (Green and Ward 2004: 7), to enact or enforce a criminal law prohibition.

Nonetheless, such reaction may still be unsatisfactory to those who consider that international law remains state-dependent-asserting that "international 
institutions and rules are generally initiated by the state which establishes the hegemony. At the very least they must have the state's support." (Cox 1993: 62-3). For some commentators, this understanding may entail presenting criminality as a mere problem of legal definition, leading to a sort of moral indifference reinforcing the structures of impunity that state criminality often entails.

While from a legal point of view the state has the authority to define what crime is and to enforce the law criminalizing those conducts, from a sociological perspective the problem of distinguishing between crime/non-crime is different from the matter of whether crime is punished. In this sense, the legal reference (and the crime) does not make vanish the problem of the political strategies employed for neutralizing the operation of the criminal law system. For instance, if the criminal code was to be destroyed in the middle of a sanguinary war by the state agents in order to perpetrate murders on a certain population "without accountability," would we still be in a society with no crime?

Let us refer to a central problem in the legalistic approach to state crime. A main issue is the alleged correspondence between conviction and crime. Jurists traditionally conceive that courts are the only body able to declare the existence of a crime and allocate responsibility for them accordingly (Tappan 1947: 100; 2001: 31 ). Nonetheless, sociologically criminality has an epistemological primacy over criminalization; in other words, the possibility for a sociological observation of the phenomenon of crime is not determined by the effectiveness (or even the presence) of a criminal justice decision.

In line with this, when Sutherland defined "white-collar crime" he asserted that

White-collar crime is ... called crime ... because it is in violation of the criminal law. The crucial question in this analysis is the criterion of violation of the criminal law. Conviction in the criminal court, which is sometimes suggested as the criterion [to determine if there is a crime], is not adequate because a large proportion of those who commit crimes are not convicted in criminal courts. (Sutherland 1940: 5)

In this regard, Sutherland assessed that courts faced a problem of class bias as well as of the influence of certain actors holding the power to impact the implementation and administration of the law (Sutherland 1940: 7). In this sense, he advanced on the criminological understanding that the implementation of the law was incidental to determining what is criminal.

Criminalization and criminality are not always convergent: some people are criminalized without having committed any crime and there are crimes that are not criminalized —indeed, most crimes are not (Hulsman 1986: 65, 70; Baratta 1991: 61; 1989: 340-1; Duff and Garland 1994: 9). 
Table 1 Problems of the Approaches to Crime

\begin{tabular}{|c|c|c|}
\hline Substantial approach & Legal approach & Extra-legal approach \\
\hline $\begin{array}{l}\text { Substantialization of } \\
\text { the criminal conduct } \\
\text { that is defined } \\
\text { according to subjective } \\
\text { essential features. }\end{array}$ & $\begin{array}{l}\text { Criminal conduct becomes a } \\
\text { mere legalistic reference, a matter } \\
\text { of syllogism confused with the } \\
\text { implementation of the code crime/ } \\
\text { non-crime by the criminal justice. }\end{array}$ & $\begin{array}{l}\text { The criminal conduct is } \\
\text { undifferentiated or ambiguous, } \\
\text { depending on the type of harm or other } \\
\text { violations of particular normative } \\
\text { parameters oriented on rights. }\end{array}$ \\
\hline
\end{tabular}

Considering the issues systematized in Table 1, our proposition is that both factuality and legal regulation should be taken into account. Unfolding a double problem in the understanding of criminality supposes recognizing that crime has no natural being. Accepting that crime has no inherent constitutive features involves that a conduct needs to be observed in reference to an institutional structure of expectation instituted through constitutive norms. In other words, crime is not only a conduct (external to the criminal law system), nor is it a mere normative expectation (for instance, one can always observe a murder without a criminal law framework); it is rather a double faceted phenomenon.

The paradoxical theory of crime (Pires 2006) proposes that the conceptualization of crime depends on a series of constitutive norms (criminal legislation). Crime understood as an "institutional fact"3 (Searle 1969, 1995, 2005) involves accepting that it may only be characterized as crime according to a reference programme. Francesco Carrara asserted that crimes were not to be conceived as "actions" but as "infractions," that is, as a form of correlation between observed actions and criminal law provisions (1859: 41 in Pires 1995: 17). In line with this view, human conduct can only be differentiated and observed as "criminal" if we take into account an institutional fact created by the criminal legislation. (Jeffery 1959: 464).

In our view, the paradoxical theory of crime applied to the understanding of state crime overcomes the dilemma built around realism and constructivism which has excluded either behaviour or normative expectations, when observing "crime." The double paradigm approach allows the observer to notice that certain "events" are problematic, as it gives legal grounds to the observation of crime. What does international law contribute for the observation of state crime?

\section{International Law Debate at the UN: Introduction and Dismissal of the Concept of State Crime}

The notion of state crime was discussed in international law à propos the debates of an international regulation on the responsibility of states. In 1930, the League of Nations, the original scenario for these debates, held a Conference 
at The Hague which resulted in a number of discussions around the topics of nationality, territorial waters and state responsibility for damage caused in their territory to foreign people or goods (UN ILC 2015). Even though since 1927 these topics had been selected in consultations with states, the Conference did not reach substantial progress on these subjects, producing only four instruments regarding nationality and territorial waters (UN ILC 2015).

The scarce agreement reached on the subject of state responsibility was attributed to the extreme complexity of the problems that the topic posed for the discussions. In fact, the League of Nations never reached an agreement to complete a codification on the matter (UN ILC 1949: 49; 2015) and the attempt to regulate this topic was only resumed in 1949, when the United Nations (UN) was in place and the ILC was trusted with the task of the progressive development of international law and its codification (UN 1947: art. 1).

In this new context and in spite of the 1930s failure to produce a codification on this matter, the ILC decided to include the topic of state responsibility in the list of topics to be studied, adding as a subtheme the criminal responsibility of states and of the people acting on their behalf. In this respect, the first study of the Commission on the codification of the responsibility for internationally wrongful conduct was authored by Commissioner García Amador. In his report, Commissioner García concluded that, even though the topic of state responsibility should be limited to public responsibility, the developments around criminal liability should be considered due to their effects on principles of public responsibility. One of these effects was the differentiation between unlawful acts and (graver) punishable acts, the former subject to compensation and the latter to sanctions (UN ILC 1954).

Such presentation of this topic anticipated the trajectory of the discussions on the matter which made constant reference to its legal consequences. Indeed, the acceptability of the notion of state crime was limited to the possibility of establishing legal consequences against its actors. In short, the debates around the draft articles indicated an analytical integration of the study of (state) crime and its consequences, as dependent and interrelated phenomena for their observation according to law.

In 1955, Commissioner García Amador was appointed Special Rapporteur for the topic of state responsibility (UN ILC 1955: 190). Right from his first report in 1956, Rapporteur García raised one of the most controversial themes of his mandate: the criminal responsibility of states. According to García, state unlawful conduct could give rise to reparations as well as to "punishment" that could take place concurrently with compensations for damage (UN ILC 1956a: 173-232).

In 1956, the ILC discussed this report. Commissioners François and Zourek rejected criminal responsibility of states. According to François, this concept "could not exist" because the state is a mere legal fiction and, as such, it could not be held criminally accountable. Additionally, he argued that the Nuremberg 
Tribunal had reintroduced the criteria that "the king can do no wrong," when establishing that unlawful acts coming from the state can only be attributed to its advisers or organs. In fact, the Nuremberg trial made clear that "crimes against international law are committed by men, not by abstract entities, and only by punishing individuals who commit such crimes can the provisions of international law be enforced." (International Military Tribunal 1947: 223). Therefore, although since the aftermath of the Second World War crimes against humanity was a typology of wrongdoing characterized as a state crime (Rodenhäuser 2014), the international tribunal restricted its reaction to the conduct of individual agents.

In this regard, Commissioner Sir Gerald Fitzmaurice, even though he agreed that this issue should not be dealt with in greater depth by the ILC (UN ILC 1956a: 241), noticed that the idea of punishing a state was not absurd and that the possibility of establishing penalties beyond restitutio in integrum was not impracticable. At the end of that meeting, the ILC Chairman concluded that the task of the ILC was to address the "public accountability" of states which had to be restricted to the duty of reparation stricto sensu, implying that criminal liability could only be attributed to individuals (UN ILC 1956a: 246). Through this last debate we can preliminarily observe from a sociological perspective how the understanding of the criminal liability is naturalized by the legal system as a process that can only implicate individuals and that has the goal of punishing them as its unequivocal and direct consequence.

In 1957, the Special Rapporteur submitted his second report (UN ILC 1957a). In this document he did not mention the possibility of awarding criminal consequences for state wrongdoing, although he warned that this was nothing but a "pending issue" that at some point the Commission would have to address (UN ILC 1957a: 105). According to the rapporteur, crimes do not necessarily lead to "punishment," but they could bear measures for the protection of the victims and their assets. In this line, in his 1958 report, he affirmed that the duty of reparation stricto sensu involves the "satisfaction" element that, as such, may entail a form of criminal liability (UN ILC 1958: 70). However, the Special Rapporteur did not examine the subject of "satisfaction" measures in greater depth. From a sociological perspective, this assertion seems to contest punishment (understood as a temporal measure of pain infliction) as the only consequence of criminal accountability, recognizing a specific weighting towards the protection of victims as an acceptable and legal form of criminal accountability.

The ILC was unable to finish a draft of the codification as the 1950s decade ended. In 1961, rapporteur García insisted on the discussion of the criminal liability of states distinguishing between two types of reparation: the reparation stricto sensu - understood as a civil institution with pecuniary implications - and satisfaction measures - understood as a type of moral and political restitution with an "essential and unvaryingly criminal feature." (UN ILC 1961: 14). The latter was 
understood as bearing two purposes: restituting the dignity of the state affected by wrong, and punishing the wrongdoer state (UN ILC 1961: 19). In this sense, the rapporteur stated that reparation stricto sensu could turn into punishment depending on the direness of the infraction.

Following the UN General Assembly Resolution 1686/1961, the ILC decided to prioritize the study of state responsibility. ${ }^{4}$ With this task the ILC Secretariat prepared a document on the criminal accountability of states, analysing the landmark discussion around the drafting of the project of the Convention on the Prevention and Punishment of Genocide. In these discussions, it was proposed that criminal liability for genocides should also cover states (UN 1948), arguing that the complexity of the structure of modern states often meant that their acts should not always be individualized on a human being, but on the system as a whole. Nonetheless, in the debates, state responsibility for genocide was rejected, meaning that only individuals could be held responsible as authors of this crime (UN ILC 1964: 126).

Concerning the antecedents, in further works the ILC Secretariat presented a compendium of international courts' decisions regarding state responsibility and the new Special Rapporteur, Roberto Ago, submitted a report on the international codification of the topic (UN ILC 1963). In these works, there was not much progress regarding the criminal liability of states. In the 1970s the topic gained momentum when the Special Rapporteur submitted a second report titled "The Origins of the International Responsibility," in which he analysed the conditions that had to be met in order to determine the existence of an internationally unlawful event. In his report, Ago stated that international law increasingly labelled as crime the grave breaches of international law coming from states-especially those infractions of erga omnes duties as well as ius cogens obligations.

In 1971, Ago submitted his third report in which he studied the international law trend criminalizing states' unlawful conduct (UN ILC 1971: 212). In this respect, the rapporteur referred to the Declaration on Principles of International Law concerning Friendly Relations and Cooperation among States approved in 1970, in which the war of aggression was defined as a crime against peace that, in accordance with international law entails public responsibility. This precedent, in his view, shaped the concept of international crime, as states are the only entities that can commit the crime of aggression. In this sense, the idea of criminal offences perpetrated by the state did not only follow from the nature of the obligations breached by the conduct or the gravity of the wrong but also derived from the fact that there were a number of conducts that only the state as a whole may perform; in other words, there are illegal actions that could not be understood as committed by individuals without a substantial reference to the organization (the state).

In 1972, the rapporteur submitted his fourth report on state responsibility, in which he asserted that wrongdoing performed by the state gives rise to 
international responsibility. Following this, in 1973 the rapporteur submitted a project regarding the general principles of state responsibility (UN ILC 1973). Despite the fact that these articles did not refer to forms of criminal responsibility, this topic was not abandoned in further discussions. With this regard, in 1974 the rapporteur declared before the ILC that, even though the articles should be limited to the study of secondary norms of responsibility (norms on the legal sanctions), it should not turn a blind eye on the content of primary obligations (norms on the obligations of states). The same observation was made by the Sixth Committee of the ILC, which affirmed that the study of state responsibility should probably take into account the existence of different types of obligations implying a distinction in their treatment according to their importance for the international community (UN ILC 1974: 6).

In accordance with this, the rapporteur proposed that the Committee consider distinguishing between grave unlawful conduct (which could be labelled as international crimes) and other less serious wrongs (UN ILC 1974: 6). From this distinction the latter would involve an obligation to make reparations while the former would entail the implementation of sanctions. This remark was based on a historical analysis that the rapporteur divided in three periods (Table 2).

Table 2 Evolution of International Law Understanding Regarding International Wrongful Acts

\begin{tabular}{|c|c|c|}
\hline $\begin{array}{l}\text { From mid-19th century until the } \\
\text { outbreak of First World War }\end{array}$ & Between 1915 and 1939 & $\begin{array}{l}\text { From the end of the Second } \\
\text { World War onwards }\end{array}$ \\
\hline $\begin{array}{l}\text { In general terms there was no } \\
\text { differentiation with regard to } \\
\text { the content of international } \\
\text { obligations violated by the } \\
\text { state. Thus, the possibility of } \\
\text { sanctioning remained only valid } \\
\text { if reparations were denied- } \\
\text { with the exception of cases of } \\
\text { aggression when it was not } \\
\text { required to make reparations } \\
\text { before taking sanction measures. }\end{array}$ & $\begin{array}{l}\text { The idea that there was not } \\
\text { a single type of international } \\
\text { wrongdoing was brought forth. } \\
\text { In this vein, there could not be } \\
\text { a single type of responsibility, } \\
\text { enabling the possibility of } \\
\text { penalizing states in line with } \\
\text { the gravity of the infraction. } \\
\text { This implied a step towards } \\
\text { a criminal connotation of the } \\
\text { international responsibility. }\end{array}$ & $\begin{array}{l}\text { It was accepted that } \\
\text { international crimes exist } \\
\text { and that, as such, they } \\
\text { should bear a corresponding } \\
\text { responsibility, entailing more } \\
\text { severe penalties. In the } 1960 \mathrm{~s} \\
\text { and } 1970 \mathrm{~s} \text {, this idea was } \\
\text { particularly relevant enabling } \\
\text { a distinction between } \\
\text { the types of international } \\
\text { wrongful acts. }\end{array}$ \\
\hline
\end{tabular}

In line with his study, the rapporteur established that the project on state responsibility should contain an article differentiating the most serious breaches from other infractions: grave breaches, he proposed, should be addressed as crimes, therefore implying more serious consequences (UN ILC 1976). In this context, in 1976, the ILC decided to include the term "state crime" in the draft articles on state responsibility (Weiler et al. 1989) in article 19 of the draft codification: 
[a]n internationally wrongful act which results from the breach by a State of an international obligation so essential for the protection of fundamental interests of the international community that its breach is recognized as a crime by that community as a whole constitutes an international crime. (UN ILC 1977: 11)

Different governments reacted to this article. Between 1980 and 1982, rapporteur Willem Riphagen, replacing Commissioner Ago, received the comments of the states. The different positions with regard to the matter of state crime could be classified in three groups, as shown in Table 3.

Table 3 States' Positions around Article 19

\section{In favour}

Belarus, Ukraine, the Soviet

Union, Yugoslavia and Bulgaria

\section{Abstention}

Canada, Austria, Spain, and the

Netherlands

\section{Against}

Sweden, Federal Republic of Germany Australia, France, Greece, Portugal and the US
These states considered article 19 as an important provision for strengthening peace, international security and the principles of the UN Charter.

\footnotetext{
These states abstained from making a definitive declaration, as the consequences to be awarded to the different categories of wrongdoing as well as an adjudicating forum with this purpose had not been clearly determined.

These states emphatically opposed article 19. The recurrent criticism within this group was that such provision would risk criminalizing the acts of states, without objective criteria: even if the definition of crimes enunciated a set of non-exhaustive examples, the debates cast doubt on the clarity of article when differentiating serious crimes.
}

The lack of consensus around article 19 was basically argued around the distinction between criminal and non-criminal conduct and the attributable consequences for state crime. Considering these objections, during the $1990 \mathrm{~s}$, there were different debates focusing on the consequences of state crime and the possible forum to decide on the criminal responsibility of states. In this respect, in 1993, the rapporteur Arangio-Ruiz submitted a report on state responsibility in which he analysed the consequences of state crime, establishing that the distinction between delicts and crimes was not merely descriptive. According to him, this involved the instatement of a regime of responsibility capable of awarding particularly serious consequences for the crimes. This connotation of state crime raised worries in different states around the problem of creating measures that could endanger the territorial integrity or the political independence of a state (UN ILC 1992). In this matter, the ILC concluded that only armed aggressions justified unilateral armed reactions and that indirectly injured states could eventually be authorized to react by a 
decision of the competent body according to the UN Charter. With this regard, the rapporteur explained that intervention should be limited to an imperative need and should be proportional in extent.

In short, the rapporteur argued that the traditional distinction between states' serious offences (with civil consequences) and wrongdoing of individuals (entailing penal consequences) should be transformed, acknowledging that states are capable of criminal conduct involving legal consequences other than civil. With this regard, the rapporteur concluded that criminal responsibility is an adequate response to states' criminal wrongdoing that should not limit legal redress to civil consequences, as well as not involving collective responsibility which he qualified as a primitive and rudimentary institution (UN ILC 1993).

In 1994, the ILC undertook a new debate on the characterization of certain illicit conduct of the state as criminal. A number of Commissioners defended the pertinence of this category, accepting that legal consequences should be awarded by an independent international body. On the other hand, other ILC members pointed out that the category of "crime of state" should not be employed because article 19 established a distinction based on the degree of seriousness of the unlawful conduct that was ambiguous for the task of attributing responsibility.

In 1995, the rapporteur focused on the consequences of international wrong, particularly with the aim of determining the adjudicating forum for establishing the breaches, labelling them as crimes and awarding subsequent sanctions (UN ILC 1995). In this regard, the rapporteur established that the general consequence of states' wrongdoing is the obligation to make reparations, including the termination of the conduct, the restitution in kind, compensation and satisfaction measures, as well as the guarantee of non-repetition. In this context, criminal conduct implies broad reparations to be made since the breach of erga omnes obligations damages the international community as a whole. Thus, although restitutio should not compromise the existence of the state and the essential needs of its population, the obligation of restoring the victim to the original situation before the gross violations could not be evaded on the basis of arguments of sovereignty, independence or prevalence of the domestic jurisdiction. Finally, the rapporteur established that, in the context of reparations, countermeasures may be invoked by the affected states, with the exception of possible unilateral interim measures for addressing a situation of genocide. From the trajectory of the discussions, we can observe the progressive emphasis of the debate around state crime on the consequences attributable to the wrongdoing.

The ILC examined this report, debating once again the concept of state crime. In this debate it was argued that the state was exempted from criminal responsibility because it was the only institution able and capable of punishing - the state punishing itself is viewed as impracticable (UN ILC 1995: 48). Additionally, it was argued that sanctioning a criminal state would unjustly extend its effects to the 
population and that the notion of state crime could stigmatize certain states as deviant, enabling eventual abusive counter-measures to be undertaken by powerful states. In spite of these oppositions, the ILC provisionally approved the draft articles on state responsibility, maintaining the original version of article 19.

In 1996, rapporteur Arangio-Ruiz was replaced by James Crawford who cast doubt on article 19, which he deemed defective regarding the definition of the criminal conduct (UN ILC 1996). In 1998, different governments raised reservations on the notion of state crime, some of them opposing the notion of crime and others objecting the possible legal consequences when attributing a criminal conduct to the state. Considering these observations, the rapporteur concluded that the term "crime" was unknot welcomed by the states; even though there was a consensus on the relevance of the category of obligations erga omnes (UN ILC 1998: 77).

In 1998, after numerous meetings and intense debates, article 19 was changed and the concept of state crime was excluded from the draft articles on state responsibility (UN 2002a). The ILC decided to exclude article 19, considering that there was no consensus regarding the notion of state crime. The dismissal of this term implied a relegation of the concept within international law. In 2000, the rapporteur presented a new report clarifying that states were capable of committing illicit conduct but criminal responsibility arising from them was only attributable to individuals. Finally, he proposed alternative wordings to the original term "crime," such as "serious unlawful international act" or "exceptionally serious unlawful act."

In 2001, the ILC adopted the draft articles on the responsibility of states for internationally wrongful acts (UN ILC 2001), replacing the concept of state crime with the concept of serious breaches of obligations to the international community as a whole and essential for the protection of its fundamental interests. On 12 December 2001, the General Assembly took note of the articles and commended them to the attention of governments without prejudice to the question of their adoption (Resolution 56/83). In 2004 (Resolution 59/35), 2007 (Resolution 62/61) and 2010 (Resolution 65/19), the General Assembly insisted on commending to the attention of governments the articles requesting the Secretary-General to invite the states to submit written observations on the future measures to be adopted, as well as preparing an initial collection of the decisions of the international bodies related to the articles.

\section{The Creation of the Legal Term "State Crime": Final Remarks from the International Law Debate}

The codification on the responsibility of states was the result of more than five decades of work. During this time the subject of state crime was widely debated. For a sociolegal characterization of state crime, this debate is not only relevant for a genealogical 
study of the notion, but also epitomizes three traditional issues when constructing a general definition of crime. What can we call a criminal action? Who can commit crime? And what are (and should be) the legal consequences of crime?

With regard to the question on the content and extent of wrongdoing that can be called crime - what can we call criminal conduct? - the ILC considered that beyond bilateral obligations, it was important to define state responsibility when "essential" international rules were breached. In line with this, the category of criminal conduct was developed by the ILC along with the international law categories of ius cogens (non-derogable norms) and obligations erga omnes (obligations opposable to all). In accordance with this, the notion of state crime emerged as an expression referring to wrongdoing resulting from the breach of essential international obligations that, as such, may be recognized as criminal by the international community as a whole (UN ILC 1977).

In 1977, this notion was adopted in article 19 of the draft codification, triggering an intense debate for two decades under the lead of different special rapporteurs on the subject (Umaña 2015). Article 19 of the draft articles was accepted by states alongside the initial debates. However, as soon as the discussion focused on the legal consequences attributable to state criminal conduct, most governments expressed their dissatisfaction with the notion and paved the way to the exclusion of the term.

A similar situation emerged with regard to the question who can do crime? ILC discussions on the codification of state responsibility focused on establishing whether states were capable of wrongdoing and, if so, what type of wrongs they could commit. Whereas some of the discussants found that states could not be addressed as criminal actors - because they are mere fictions that should not be submitted to criminal law (societas delinquere non potest); others sustained that states could be regarded as criminal actors when they supported, acquiesced or participated in criminal conduct. This was confirmed by the fact that certain criminal conduct, such as the crime of aggression, apartheid or annexation, could only be perpetrated by states. Furthermore, this category is relevant when criminal actions are performed through complex networks making it difficult to concentrate responsibilities on individuals.

For some time, ILC discussions were in favour of understanding the state as a criminal actor. However, this option was discarded and the state was finally framed as a non-criminal actor, particularly because of reluctance to assess the consequences of such categorization of wrongdoing and the appropriate forum for the attribution of responsibility. These debates revealed that the acceptability of the notion of state crime was not only a matter of naming a wrong and blaming the state for it but concerned the question of what are (and should be) the legal consequences of crime? In this respect, ILC debates presented different theoretical 
problems concerning the possibility of awarding criminal law consequences to state wrongdoing under the traditional framework of punitive measures, as well as more practical issues in respect to the operational elements of such responsibility-e.g. the adjudicating forum for determining breaches and the procedures and rules of attribution and allocation of responsibility.

While some governments and ILC Commissioners supported the idea of state crime as an adequate label for the most serious offences under the general principle of the international responsibility for state wrongdoing, others argued that it had to be abandoned due to the impracticability of adequate legal consequences and pertinent adjudicatory institutions for state crime. Hence, the different issues around the category of state crime became progressively dependent on the possibility of finding an "adequate" criminalization. Thus, in 1998 this concept was "put to one side" due to the lack of consensus on its content and of the regime of responsibility that it should be granted with (UN ILC 1998). The replacement of state crime by the notion of "serious breaches" was mainly based on the objections referring to the legal consequences for states' criminal wrongdoing (Wyler 2002; Bagchi 2009: 10).

The study of the possible legal consequences of state crime underlines the difficulty of using law to assess crimes without a reference to attributable penalties. This idea seems to be governed by the assumption of the necessity of punishment for countervailing criminal conduct. Indeed, the study of the genealogy of the ILC discussions allows us to visualize a distinction drawn between civil law consequences and criminal law consequences. In line with the traditional distinction between penal measures and compensatory measures, the former (sanctions) are attributable "by nature" to criminal conducts and the latter (compensations) to civil wrongdoing. Do legal consequences attributable to wrongdoing have any essential or natural feature? The fact that reparations presented a penal element (e.g. punitive damages in tort cases) and other sanctions were found to have a compensatory element (e.g. compensation for criminal injuries) did not persuade the discussants of the lack of a natural bond between a particular measure and the sort of wrong materialized in the conduct.

When dealing with the conceptualization of state crime, international law draws a necessary conceptual correlation between the phenomena of crime and its criminalization. As such, (state) crime could not be conceptualized without an attributable consequence entailing the criminalization of the conduct. The common legal understanding is that only the law can define a crime and the applicable punishment. In this line, the formula assessing that there shall be no punishment without a crime was inverted by the discussion to a logic of no crime without applicable punishment. In short, when limiting the concept of state crime to the possibility of finding practicable legal consequences, international law situates criminality and criminalization as two fields of observation intrinsically concomitant. Hence, the 
absence of viable means or basis for the criminalization of an action was observed as an argument for making the criminal category (state crime) impertinent.

The study of the concept of state crime in international law illustrates the limitations of evaluating the phenomenon of criminality reduced to the notion of criminalization. This scope should be widened when constructing a socio-legal conceptualization of the phenomenon: for a sociological observation of (state) criminality, criminalization is a contingency. These are two phenomena that need to be addressed as independent fields of observation and, as such, although related they are not necessarily conceptually nor practically interconnected. The conceptualization of state crime does not require a determination, or even the existence, of criminal law consequence (penalization) — notwithstanding valid attempts to create mechanisms of legal redress.

With the aim of drawing a socio-legal conceptualization of impunity, a characterization of the phenomenon of crime should allow us to uncouple the observation of criminal conduct and the extent, form and aim of its criminalization. In other words, the reconstruction and characterization of the (state) criminal conduct may be drawn independently from the (still relevant) task of debating the legal redress and the problem of impunity. In this regard, we have the task of identifying the cognitive, operational, procedural and ideological obstacles for visualizing legal consequences to the criminal phenomenon and their particular meaning and weight for the conceptualization of impunity.

\section{Notes}

1. "Only recently have criminologist studied state crime. Yet, state crime has been approached in a number of ways by a number of disciplines (i.e., criminology, history, political science, sociology)." (Rothe 2009: 1).

2. Question inspired by Feinberg (1990: 7).

3. Searle $(1969,1995)$, distinguishing between brute facts and institutional facts, assesses that the latter can exist only within human institutions (such as money or sentences), while brute facts exist quite independently of any institution capable of formulating constitutive rules of the form $\mathrm{X}$ counts as $\mathrm{Y}$ in C (Searle 2005: 11).

4. With this purpose, the ILC conformed a subcommittee on the matter. This organ submitted its 1963 and 1964 reports on the issue of state responsibility (UN ILC 1964: 126).

\section{References}

Arendt, H. (1973) On Revolution. London: Penguin.

Bagchi, A. (2009) "Intention, Torture, and the Concept of State Crime", Penn State Law Review, 114(1). Available online at: http://scholarship.law.upenn.edu/faculty_scholarship/321.

Barak, G. (1990) "Crime, Criminology and Human Rights: Towards an Understanding of State Criminality", Journal of Human Justice, 2(1): 11-28. 
Barak, G. (2015) The Routledge International Handbook of the Crimes of the Powerful. London: Taylor \& Francis.

Baratta, A. (1989) "Derechos Humanos: entre violencia estructural y violencia penal", in A. Baratta, Criminología y sistema penal. Compilación in memoriam. B de F Ltda: Montevideo, 2004, 334-56.

Baratta, A. (1991) "Funciones instrumentales y simbólicas del derecho penal: una discusión en la perspectiva de la criminología crítica", in A. Baratta, Criminología y sistema penal. Compilación in memoriam. B de F Ltda: Montevideo, 2004, 57-88.

Baratta, A. (2004a) "Derechos Humanos: entre violencia estructural y violencia penal", in A. Baratta, ed., Criminología y sistema penal. Compilación in memoriam. Montevideo: B de F Ltda.

Baratta, A. (2004b) "Funciones instrumentales y simbólicas del derecho penal: una discusión en la perspectiva de la criminología crítica", in A. Baratta, ed., Criminología y sistema penal. Compilación in memoriam. Montevideo: B de F Ltda.

Carson (1979) Wyvonia Carson v. State of Indiana. Supreme Court of Indiana.

Chambliss, W. (1989) “A Sociological Analysis of the Law of Vagrancy”, Social Problems, Vol. 12: $67-78$.

Chambliss, W. (1995) “Commentary by William Chambliss", Society of Social Problems Newsletter, 26(2).

Chambliss, W., Michalowski, R. and Kramer, R. (2010) State Crime in the Global Age. Cullompton: Willan.

Cohen, S. (1993) "Human Rights and Crimes of the State: The Culture of Denial", Australian and New Zealand Journal of Criminology, Vol. 26: 97-115.

Cox, C.B. (1993) “On Michael Levin's "Responses to Race Differences in Crime”, Journal of Social Philosophy, 24(1): 155-62.

Doig, A. (2011) State Crime. Cullompton: Willan Publishing.

Drost, P. (1959) The Crime of State: Penal Protection for Fundamental Freedoms of Persons and Peoples. Leiden: A.W. Sythof.

Duff, R. and Garland, D. (1994) "Introduction: Thinking about Punishment", in R. Duff and D. Garland, eds., A Reader on Punishment. Oxford: Oxford University Press.

Feinberg, J. (1990) The Moral Limits of the Criminal Law, vol. 4. Harmless Wrongdoing. Oxford: Oxford University Press.

Friedrichs, D.O. and Schwartz, D.M. (2007) "Editors' Introduction: On Social Harm and a TwentyFirst Century Criminology", Criminal Law Social Change, Vol. 48: 1-7.

Giddens, A (1987) Social Theory and Modern Sociology. Stanford, CA: Polity Press.

Green, P. and Ward, T. (2000) "State Crime, Human Rights, and the Limits of Criminology", Social Justice, 76(27): 101-15.

Green, P. and Ward, T. (2004) State Crime: Governments, Violence and Corruption. London: Pluto Press.

Hart, H.L.A. (2012) The Concept of Law. Oxford: Oxford University Press.

Heller, K. (2016) "What is an International Crime? (A Revisionist History)", Harvard International Law Journal, 58(2): 353-420.

Hulsman, L. (1986) "Critical Criminology and the Concept of Crime", Contemporary Crises, 10(1): $63-80$.

International Military Tribunal (1947) Trial of the Major War Criminals before the International Military Tribunal, vol. 1. Nuremberg.

Jeffery, R. (1959) “An Integrated Theory of Crime and Criminal Behavior”, Journal of Criminal Law and Criminology, 49(6): 533-52. 
Jørgensen, N. (2000) The Responsibility of States for International Crimes. Oxford: Oxford University Press.

Kramer, R.C. (1990) "State-Corporate Crime", paper presented at the North Central Sociological Association and the Southern Sociological Association, Louisville, KY.

Kramer, R.C. (1992) “The Space Shuttle Challenger Explosion”, in K. Schlegel and D. Weisburd, eds., White Collar Crime Reconsidered. Boston: North East University Press.

Kramer, R.C. and Michalowski, R.J. (1991) "State-Corporate Crime", prepared for American Society of Criminology Meeting, Baltimore, MD, 7-12 November1990.

Kramer, R., Michalowski, R. and Kauzlarich, D. (2002) "The Origins and Development of the Concept and Theory of State-Corporate Crime", Crime and Delinquency, 48(2): 263-82.

Kramer, R., Michalowski, R. and Rothe, D. (2005) "The Supreme International Crime: How the U.S. War in Iraq Threatens the Rule of Law", Social Justice, 32(2): 100.

MacCormick, N. (2007) Institutions of Law: An Essay in Legal Theory. Oxford: Oxford University Press.

Matthews, R.A. and Kauzlarich, D. (2007) "State Crimes and State Harms: A Tale of Two Definitional Frameworks", Crime, Law and Social Change, Vol. 48: 43-55.

Pires, A. (1995) "La criminologie d'hier et d'aujourd'hui", in C. Debuyst, F. Digneffe, J.M. Labadie and A.P. Pires, eds., Histoire des savoirs sur le crime et la peine, vol. 1. Des savoirs diffus au criminel-né (1701-1876). Brussels: De Boeck Université et Larcier.

Pires, A. (2001) "La ligne Maginot en droit pénal: La protection contre le crime versus la protection contre le Prince", Revue de droit pénal et de criminologie (Brussels), 81(2): 145-70.

Pires, A. (2006) "Consideraciones preliminares para una teoría del crimen como objeto paradojal", Revista Ultima Ratio, 1(0): 213-55.

Prins, H. (2014) "Mental Disorder, Criminality and the Literary Imagination", Howard Journal of Criminal Justice, 53(3): 290-308.

Proal, L. (1898) Political Crime. New York: D. Appleton \& Co.

Rodenhäuser, T. (2014) "Beyond State Crimes: Non-State Entities and Crimes Against Humanity", Leiden Journal of International Law, 27(4): 913-28

Ross, J. (2000) "Controlling Crimes by the Military", in J.I. Ross, eds., Controlling State Crime. New Brunswick, NJ: Transaction Publishers.

Ross, J (2003) The Dynamics of Political Crime. Thousand Oaks, CA: Sage Publications.

Rothe, D. (2009). State Criminality: The Crime of All Crimes. Lanham, MD: Lexington Books.

Ruggiero, V. (2013) "The Crimes of the Economy: A Criminological Analysis of Economic Thought", British Journal of Criminology, 54(5): 978-980.

Searle, J.R. (1969) Speech Acts: An Essay in the Philosophy of Language. London: Cambridge University Press.

Searle, J.R. (1995) The Construction of Social Reality. New York: Free Press.

Searle, J.R. (2005) "What is an Institution?", Journal of Institutional Economics, 1(1): 1-22.

Schwendinger, H. and Schwendinger, J. (2014) "Defenders of Order or Guardians of Human Rights? (Foundations)", Social Justice, 40(1-2): 87-117.

Sutherland, E. (1940) "White-Collar Criminality", American Sociological Review, 5(1): 1-12.

Tappan, P. (1947) “Who is the Criminal?”, American Sociological Review, 12(1): 96-102.

Tappan, P. (2001) "Who is the Criminal?", in S. Henry and M. Lanier, eds., What is Crime? New York: Rowman \& Littlefield.

Tilly, C. (1985) "War Making and State Making as Organized Crime", in P.B. Evans, ed., Bringing the State back in. Cambridge: Cambridge University Press. 
Umaña, C. (2015) “Crímenes de Estado: ¿un concepto válido para el derecho internacional?”, Serie Documentos de Trabajo Departamento de Derecho Constitucional, Vol. 8: 1-36.

UN (1947) Statute of the International Law Commission, General Assembly, Resolution 174 (II) of 21 November 1947, amended by resolutions 485 (V) of 12 December 1950, 984 (X) of 3 December 1955, 985 (X) of 3 December 1955 and 36/39 of 18 November 1981.

UN (1948) Genocide: Draft Convention and Report of the Economic and Social Council, Doc. A/C.6/236.

UN (1989) Report of the Working Group on Enforced - or Involuntary - Disappearances: Addendum Report on the Visit to Colombia by Two Members of the Working Group on Enforced or Involuntary Disappearances, Distr. GENERAL E/CN.4/1989/18/Add. 6 February 1989 (24 October-2 November 1988).

UN (1990) Informe del Relator Special de las Naciones Unidas sobre ejecuciones sumarias o arbitrarias sobre la visita a Colombia realizada del 11 al 20 de octubre de 1989, Doc. E/CN.4/1990/22/Add.1.

UN (1996) Set of Principles for the Protection and Promotion of Human Rights through Action to Combat Impunity, 20 June 1996, Doc. E/CN.4/Sub.2/1996/18.

UN (1997) Set of Principles for the Protection and Promotion of Human Rights through Action to Combat Impunity, 2 October 1997, Doc. E/CN.4/Sub.2/1997/20/Rev.1.

UN (1998) First Report on State Responsibility, by Mr. James Crawford, Special Rapporteur, Doc. A/ CN.4/490 and Add. 1-7.

UN ILC (1949) Yearbook of the International Law Commission 1949. Summary Records and Documents of the First Session including the report of the Commission to the General Assembly.

UN ILC (1949) Yearbook of the International Law Commission 1949. Summary Records and Documents of the First Session Including the Report of the Commission to the General Assembly.

UN ILC (1954) Request of the General Assembly for the Codification of the Principles of International Law Governing State Responsibility, Memorandum by Mr. F.V. Garcia-Amador, Doc. A/CN.4/80.

UN ILC (1955) Yearbook of the International Law Commission, vol. 1. Summary Records of the Seventh Session, 2 May-8 July 1955, Doc. A/CN.4/SER.A/1955.

UN ILC (1956a) Yearbook of the International Law Commission, vol. 1. Doc. A/CN.4/96.

UN ILC (1956b) Yearbook of the International Law Commission, vol. 2. Doc. A/CN.4/96.

UN ILC (1957a) International Responsibility. Second Report by F.V. Garcia Amador, Special Rapporteur, Doc. A/CN.4/106.

UN ILC (1957b) Yearbook of the International Law Commission, vol. 2. Doc. A/CN.4/SER.A/1957/Add.1.

UN ILC (1958) Yearbook of the International Law Commission, vol. 2, Doc. A/CN.4/SER.A/1958/Add.1.

UN ILC (1961) Yearbook of the International Law Commission, vol. 2, Doc. A/CN.4/SER.A/1961/Add.1.

UN ILC (1963) Yearbook of the International Law Commission, vol. 2, Doc. A/CN.4/163.

UN ILC (1964) Yearbook of the International Law Commission, vol. 2, Doc. A/CN.4/SER.A/1964/ADD.1.

UN ILC (1971) Yearbook of the International Law Commission, vol.2, part 1, Tercer informe sobre la responsabilidad de los Estados, por el Sr. Roberto Ago, Relator Special. - El hecho internacionalmente ilicito del Estado como fuente de responsabilidad internacional. Doc. A/CN.4/246y Add.la3.

UN ILC (1973) Yearbook of the International Law Commission, vol. 2, Doc. A/CN.4/SER.A/1973/Add.1.

UN ILC (1974) Yearbook of the International Law Commission, vol. 1, Doc. A/CN.4/SER.A/1974.

UN ILC (1975) Yearbook of the International Law Commission, vol. 2, Doc. A/CN.4/SER.A/1975/Add.1.

UN ILC (1976) Yearbook of the International Law Commission, vol. 2, part 1, Doc. A/CN.4/ SER.A/1976/Add.1 (Part 1).

UN ILC (1977) Yearbook of the International Law Commission, vol. 2, part 2, Doc. A/CN.4/ SER.A/1977/Add.1 (Part 2).

UN ILC (1978) Yearbook of the International Law Commission, vol. 2, part 2, Doc. A/CN.4/ SER.A/1978/Add.1 (Part 2). 
UN ILC (1980) Yearbook of the International Law Commission, vol. 2, part 1, Doc. A/CN.4/ SER.A/1980/Add.1 (Part 2).

UN ILC (1981) Yearbook of the International Law Commission, vol. 2, part 1, Doc. A/CN.4/ SER.A/1981/Add.1 (Part 2).

UN ILC (1983) Yearbook of the International Law Commission, vol. 2, part 2, Doc. A/CN.4/ SER.A/1983/Add.1 (Part 2).

UN ILC (1985) Yearbook of the International Law Commission, vol. 2, part 1, Doc. A/CN.4/ SER.A/1985/Add.1 (Part 1).

UN ILC (1992) Yearbook of the International Law Commission, vol. 1, Doc. A/CN.4/SER.A/1992.

UN ILC (1993) Yearbook of the International Law Commission, vol. 2, part 2, Doc. A/CN.4/ SER.A/1993/Add.1 (Part 2).

UN ILC (1994) Yearbook of the International Law Commission, vol. 2, part 2, Doc. A/CN.4/ SER.A/1994/Add.1 (Part 2).

UN ILC (1995) Yearbook of the International Law Commission, vol. 2, part 2, Doc. A/CN.4/ SER.A/1995/Add.1 (Part 2).

UN ILC (1996) Yearbook of the International Law Commission, vol. 2, part 2, Doc. A/CN.4/ SER.A/1996/Add.1 (Part 2).

UN ILC (1998) Yearbook of the International Law Commission, vol. 2, part 2, Doc. A/CN.4/ SER.A/1998/Add.1 (Part 2).

UN ILC (2000) Yearbook of the International Law Commission, vol. 2, part 2, Doc. A/CN.4/ SER.A/2000/Add.1 (Part 2)/Rev.1.

UN ILC (2001) "Draft Articles on Responsibility of States for Internationally Wrongful Acts, with Commentaries", Yearbook of the International Law Commission, vol. 2, part 2, Doc. A/CN.4/ SER.A/2001/Add.1 (Part 2).

UN ILC (2008) Immunity of State Officials from Foreign Criminal Jurisdiction, Doc. A/CN.4/601. Preliminary report on immunity of State officials from foreign criminal jurisdiction, by Roman Anatolevich Kolodkin, Special Rapporteur.

UN ILC (2015) About the Commission. Origin and Background.

Vincent, A. (2012) "Can States Commit Crimes?", in S. Bronitt, M. Gani and S. Hufnagel, eds., Shooting to Kill: Socio-Legal Perspectives on the Use of Lethal Force. Portland, OR: Hart Pub.

Ward, T. (2013) "Expert Evidence, Ethics and the Law", in K. Harrison and B. Rainey, eds., The WileyBlackwell Handbook of Legal and Ethical Aspects of Sex Offender Treatment and Management, 1st edn. Hoboken, NJ: John Wiley \& Sons.

Weiler, J.H., Cassese, A. and Spinedi, M. (1989) International Crimes of State: A Critical Analysis of the ILC's Draft Article 19 on State Responsibility, Volume 10. Berlin: Walter de Gruyter.

Wyler, E. (2002) 'From 'State Crime' to Responsibility for 'Serious Breaches of Obligations under Peremptory Norms of General International Law", European Journal of International Law, 13(5): 1147-60. 